\title{
The Colony Church Site (41RA31): A Caddo Mound Center in the Upper Sabine River Basin, Rains County, Texas
}

Timothy K. Perttula

Heritage Research Center, Stephen F. Austin State University

Follow this and additional works at: https://scholarworks.sfasu.edu/ita

Part of the American Material Culture Commons, Archaeological Anthropology Commons, Environmental Studies Commons, Other American Studies Commons, Other Arts and Humanities Commons, Other History of Art, Architecture, and Archaeology Commons, and the United States History Commons

Tell us how this article helped you.

This Article is brought to you for free and open access by the Center for Regional Heritage Research at SFA ScholarWorks. It has been accepted for inclusion in Index of Texas Archaeology: Open Access Gray Literature from the Lone Star State by an authorized editor of SFA ScholarWorks. For more information, please contact cdsscholarworks@sfasu.edu. 


\section{The Colony Church Site (41RA31): A Caddo Mound Center in the Upper Sabine}

River Basin, Rains County, Texas

\section{Creative Commons License}

\section{(c) (1) \&}

This work is licensed under a Creative Commons Attribution-NonCommercial 4.0 International License 


\title{
The Colony Church Site (41RA31): A Caddo Mound Center in the Upper Sabine River Basin, Rains County, Texas
}

\author{
Timothy K. Perttula
}

\section{INTRODUCTION}

The Colony Church site (41RA31) is an ancestral Caddo mound center in the Post Oak Savannah of the upper Sabine River basin in East Texas (Figure 1); it is the westernmost Caddo mound site on the Sabine River. The site was recorded in the late 1960s, as part of an archaeological survey of the proposed Mineola Reservoir on the Sabine River (Malone 1970). The reservoir was never constructed.

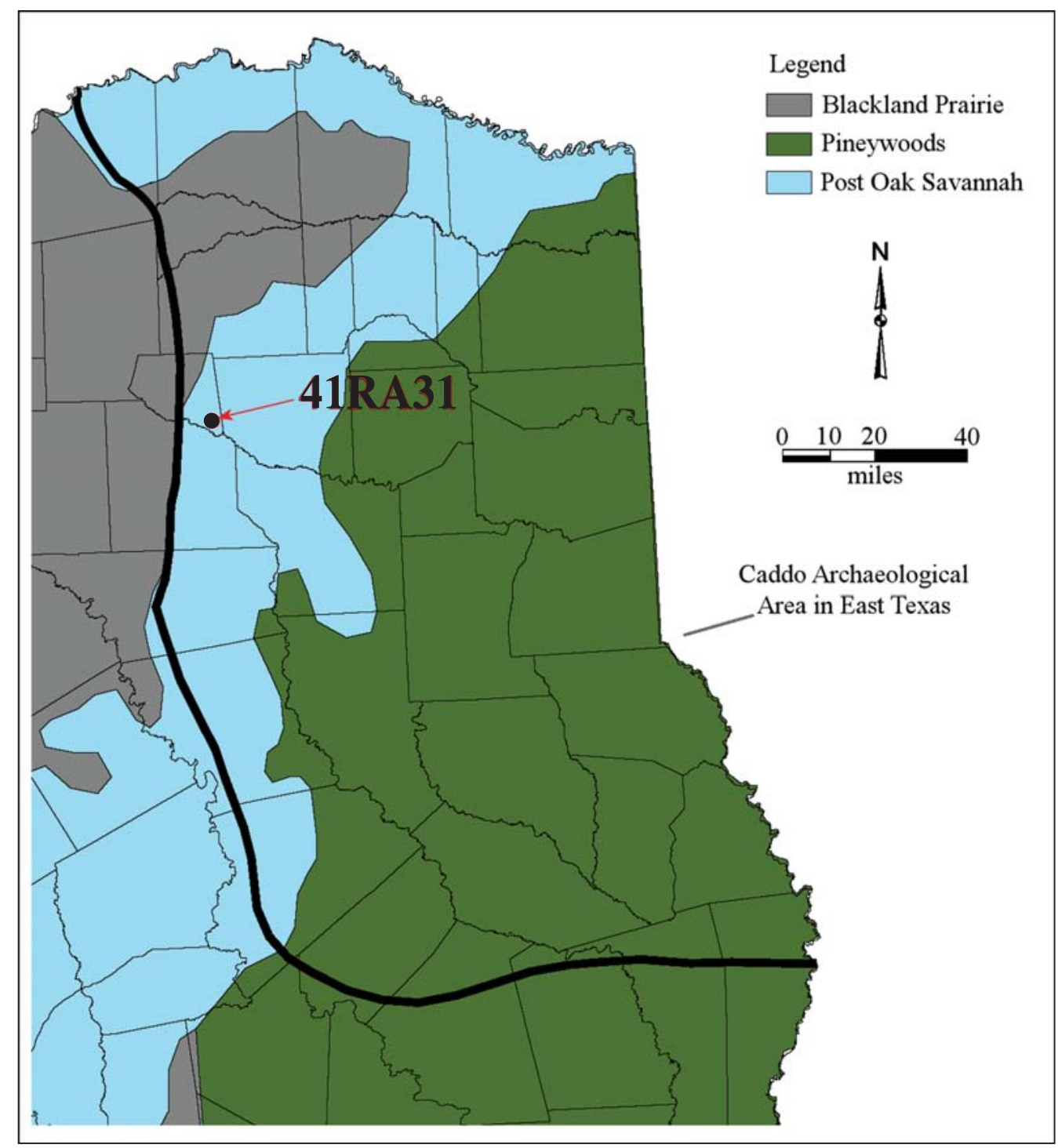

Figure 1. The location of the Colony Church site (41RA31) in East Texas. 


\section{SITE SETTING}

The Colony Church site is located on a sandy alluvial terrace on the east side of Big Creek, a southwardflowing tributary to the Sabine River (Figure 2). From surface artifact evidence, the site is estimated to cover a $60 \times 100 \mathrm{~m}$ area (ca. 1.5 acres) of the terrace.

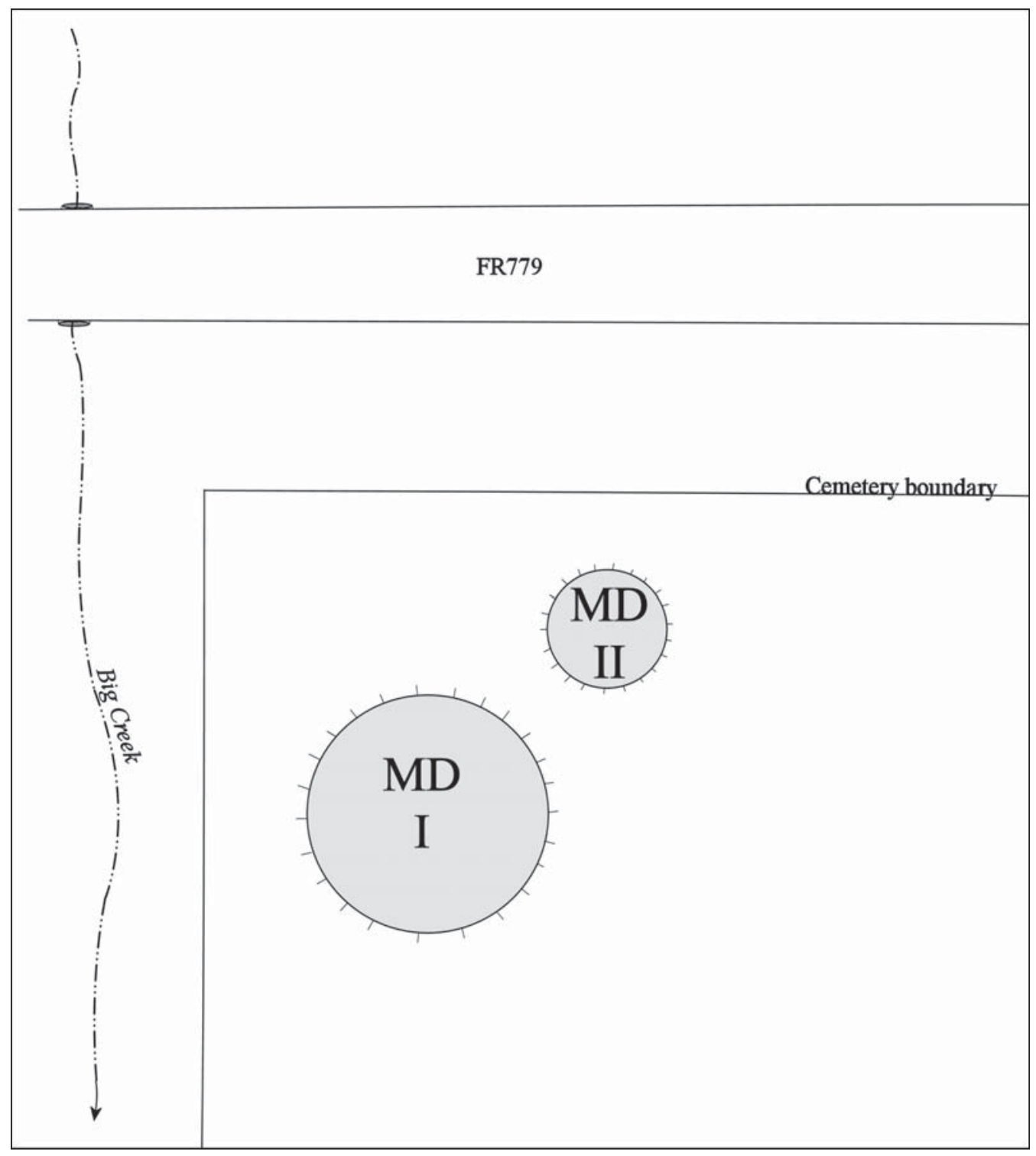

Figure 2. Map of the Colony Church site (41RA31).

The site is within the boundaries of a 19th and 20th century Anglo-American cemetery. Caddo ceramic sherds were noted on the surface by Malone (1970) where they were eroding from graves and the sandy soils. Two mounds (I and II) have been recorded at the site: Mound I, ca. $20 \mathrm{~m}$ in diameter and $1 \mathrm{~m}$ in height, and Mound II, ca. $10 \mathrm{~m}$ in diameter and $1 \mathrm{~m}$ in height (see Figure 2).

There was no evidence that either mound had been dug into at the time they were recorded by Malone (1970). Their size and height suggests that both mounds were probably constructed over important buildings that would have been used by the Caddo religious and political elite for rituals and ceremonies (see Girard et al. 2014:77-81). The buildings would have been burned and then buried by mound sediments. When Malone 
recorded the mounds, they both had visible charcoal-stained areas, likely evidence of the burned structures that lie under the mound fill.

\section{ARTIFACT ASSEMBLAGE}

The small artifact assemblage from the Colony Church site was gathered from a surface collection; no shovel tests or other subsurface excavations were conducted at the site at that time. The artifact assemblage includes chipped stone tools $(n=3)$, plain and decorated ceramic sherds $(n=319)$ from plain, utility, and fine ware vessels, one long-stemmed Red River pipe sherd, and three pieces of daub.

\section{Chipped Stone Tools}

Chipped stone tools in the collection from the Colony Church site include an arrow point tip (made from a local red chert), a Woodland period Godley dart point, and a unifacially-worked gouge made from a local petrified wood. The Godley point is on a non-heat-treated local quartzite.

\section{Ceramic Vessel Sherds}

The ceramic vessel sherd collection from the Colony Church site is comprised of 319 sherds from plain ware, utility ware, and fine ware vessels (Table 1). The plain to decorated sherd ratio is 4.3:1. Given that 37 percent of the rims in the assemblage are from plain wares, it is clear that plain ware vessels are relatively abundant at the site. Utility ware rim sherds account for 41 percent of the rims in the assemblage.

Table 1. Temper noted in ceramic sherds from the Colony Church site.

\begin{tabular}{lrrrrrr} 
& \multicolumn{3}{c}{ grog temper } & \multicolumn{3}{c}{ bone temper } \\
Ware & rim & body & base & rim & body & N \\
\hline Plain & 9 & 213 & 6 & 1 & 30 & 259 \\
Utility & 10 & 18 & - & 1 & 2 & 31 \\
Fine & 4 & 19 & - & 2 & 4 & 29 \\
\hline Totals & 23 & 250 & 6 & 4 & 36 & 319 \\
\hline
\end{tabular}

More than 87 percent of the sherds in the assemblage are from grog-tempered vessels (see Table 1), and the remainder are tempered with crushed and burned bone. The highest proportion of bone temper use is in the fine wares (20.7 percent), particularly in the sherds from red-slipped vessels. The proportion of bone-tempered ceramics is comparable to other upper Sabine River basin sites that predate ca. A.D. 1400 (Bruseth and Perttula 1981:Table 5-6 and Figure 5-3).

Sherds from utility ware vessels (i.e., sherds from vessels with wet paste designs) comprise 52 percent of the decorated sherds from the Colony Church site (see Table 1). About 68 percent of the utility ware sherds have incised decorative elements, along with incised-punctated ( 3 percent), lip notched ( 3 percent), and punctated (26 percent) elements (Table 2 ). 
Table 2. Decorative elements in the utility ware sherds from the Colony Church site.

\begin{tabular}{|c|c|c|c|c|c|}
\hline \multirow[b]{2}{*}{ Decorative element } & \multicolumn{2}{|c|}{ grog } & \multicolumn{2}{|c|}{ bone } & \multirow[b]{2}{*}{$\mathrm{N}$} \\
\hline & rim & body & rim & body & \\
\hline \multicolumn{6}{|l|}{ Incised } \\
\hline cross-hatched lines & 4 & 1 & 1 & - & 6 \\
\hline diagonal lines, L-R & 1 & 1 & - & - & 2 \\
\hline diagonal lines, R-L & 1 & 1 & - & - & 2 \\
\hline diagonal opposed lines & - & 1 & - & - & 1 \\
\hline $\begin{array}{l}\text { diagonal opposed lines forming } \\
\text { triangle elements }\end{array}$ & 1 & - & - & - & 1 \\
\hline parallel lines & - & 6 & - & 1 & 7 \\
\hline straight line & - & 2 & - & - & 2 \\
\hline Subtotal, Incised & 7 & 12 & 1 & 1 & 21 \\
\hline \multicolumn{6}{|l|}{ Incised-Punctated } \\
\hline $\begin{array}{l}\text { diagonal incised lines forming } \\
\text { triangles filled with rows of } \\
\text { tool punctates }\end{array}$ & 1 & - & - & - & 1 \\
\hline Lip notched, R-L & 1 & - & - & - & 1 \\
\hline \multicolumn{6}{|l|}{ Punctated } \\
\hline fingernail punctate, single & - & 1 & - & - & 1 \\
\hline tool punctate, single & - & - & - & 1 & 1 \\
\hline tool punctated rows & - & $5^{*}$ & - & - & 5 \\
\hline tool punctated rows, diagonal & 1 & - & - & - & 1 \\
\hline Subtotal, Punctated & 1 & 6 & - & 1 & 8 \\
\hline Totals & 10 & 18 & 1 & 2 & 31 \\
\hline
\end{tabular}

*one sherd on a raised rim collar; $\mathrm{L}=\mathrm{left}$; $\mathrm{R}=$ right

The incised sherds are from Canton Incised vessels (see Suhm and Jelks 1962:Plate 12). Principal motifs include cross-hatched incised and diagonal incised lines (oriented either from left to right or from right to left on the rim) (Figure 3b-c). The one incised-punctated rim sherd (Figure 3a) is also from a Canton Incised vessel: it has sets of diagonal incised lines that formed a series of triangles around the rim that are filled with rows of tool punctates (see Suhm and Jelks 1962:Plate 12d, h).

One rim in the Colony Church utility wares has diagonal notching on the lip. The notching of the lips of vessels at the sole rim decoration is an apparently distinctive, although not common, decorative method in a number of different Caddo communities of different ages in East Texas. The earliest assemblages, dating from ca. A.D. 900-1200, with lip notched vessels occur in the upper Red, upper and middle Sabine, and in the Angelina River basins (Perttula 2015:Figure 9). Middle Caddo period (ca. A.D. 1200-1400) communities where lip notched ceramics are found include the same previously mentioned assemblages, as well as sites in the Big Cypress Creek basin.

The punctated sherds have horizontal and diagonal rows of either fingernail $(n=1)$ or tool $(n=7)$ punctations on the rim and/or body of utility ware jars (see Table 2; see also Suhm and Jelks 1962:Plate 80). Sherds 


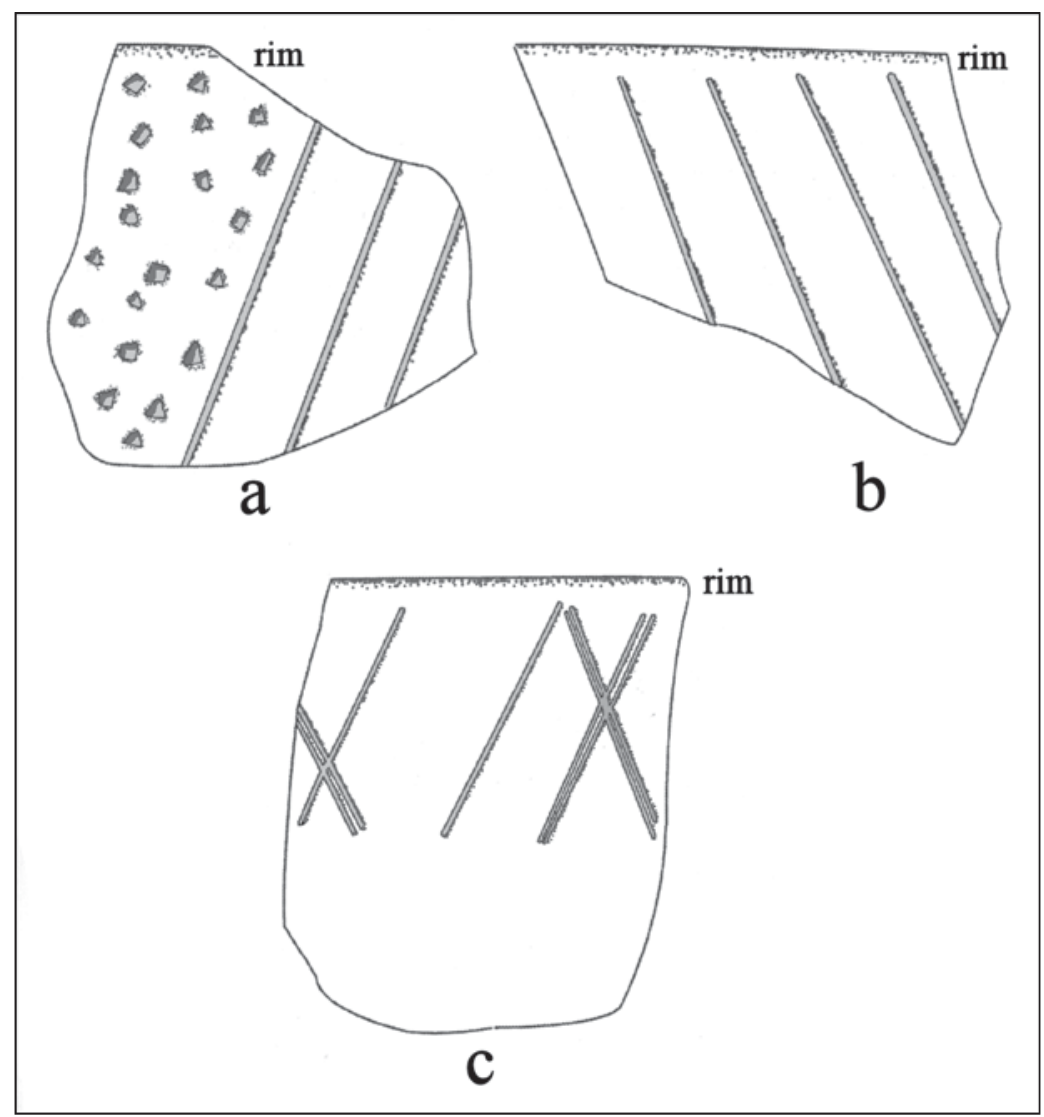

Figure 3. Decorative elements on utility ware rim sherds: a, incisedpunctated; b-c, incised.

with punctated decorative elements are abundant in ca. A.D. 900-1400 Caddo ceramic assemblages in sites at nearby Lake Fork Reservoir (see Bruseth and Perttula 1981:Tables 5-3 and 5-9).

The fine ware sherds (i.e., sherds from vessels decorated after the vessel was leather-hard or had been fired) from the Colony Church site include sherds from engraved vessels (17 percent), engraved-appliqued vessels (3.4 percent), and red-slipped vessels (79 percent) (Table 3). The abundance of sherds from redslipped vessels is particularly notable.

Table 3. Decorative elements in the fine ware sherds from the Colony Church site.

\begin{tabular}{|c|c|c|c|c|c|}
\hline \multirow[b]{2}{*}{ Decorative element } & \multicolumn{2}{|c|}{ grog } & \multicolumn{2}{|c|}{ bone } & \\
\hline & rim & body & rim & body & $\mathrm{N}$ \\
\hline
\end{tabular}

\section{Engraved}

diagonal opposed lines*

hatched pendant triangles

parallel lines

straight line

triangle elements*

Subtotal, Engraved

1
1
-
-
1
3

$\begin{array}{lll}- & - & 1 \\ - & - & 1 \\ - & - & 1 \\ - & - & 1 \\ - & - & 1 \\ - & - & 5\end{array}$


Table 3. Decorative elements in the fine ware sherds from the Colony Church site, cont.

\begin{tabular}{|c|c|c|c|c|c|}
\hline \multirow[b]{2}{*}{ Decorative element } & \multicolumn{2}{|c|}{ grog } & \multicolumn{2}{|c|}{ bone } & \multirow[b]{2}{*}{$\mathrm{N}$} \\
\hline & rim & body & rim & body & \\
\hline \multicolumn{6}{|l|}{ Engraved-Appliqued } \\
\hline $\begin{array}{l}\text { diagonal lines and diagonal } \\
\text { appliqued ridge }\end{array}$ & 1 & - & - & - & 1 \\
\hline \multicolumn{6}{|l|}{ Red-Slipped } \\
\hline ext. red-slipped & - & 11 & - & 1 & 12 \\
\hline int./ext. red-slipped & - & 6 & 2 & 3 & 11 \\
\hline Subtotal, Red-Slipped & - & 17 & 2 & 4 & 23 \\
\hline Totals & 4 & 19 & 2 & 4 & 29 \\
\hline
\end{tabular}

*also red-slipped on interior and exterior surfaces

The grog-tempered engraved rim and body sherds are from Sanders Engraved carinated bowls (Figure 4bd; see also Suhm and Jelks 1962:Plate 69a, g, i, and Bruseth and Perttula 1981:Figure 5-6). Two of the Sanders Engraved rim sherds also have a red slip on interior and exterior surfaces (Figure $4 \mathrm{c}-\mathrm{d}$ ). The one engravedappliqued rim sherd (Figure 4a) from a carinated bowl in the fine wares from the Colony Church site may be a variety of Sanders Engraved in that the rim has a diagonal engraved line alongside a diagonal appliqued ridge.

The many red-slipped rim and body sherds in the fine wares from the Colony Church site are from Sanders Plain carinated bowls and bottles. As redefined by Brown (1996:401-403 and Figures 2-191, 2-34g, 2-37a-1, 2-38d, 2-39d, k, n-q, and 2-42b), Sanders Plain is a grog-tempered, slipped, and undecorated type found widely across the Caddo area. Vessel forms include bowls, carinated bowls, and narrow and wide-mouthed bottles.

Red-slipped fine wares (bowls, carinated bowls, and an occasional bottle) are a common part of ancestral Caddo ceramic assemblages in several parts of East Texas, most notably in sites in the middle Red River, the Big Cypress Creek basin, the upper Sulphur and Sabine River basin, and the middle Sabine River basin. They are particularly common in pre-A.D. 1400 ceramic assemblages at sites such as Jamestown (41SM54), Sam Kaufman (41RR16), A. C. Mackin (41LR31), Harling (41FN1), and Sanders (41LR2) on the Sabine and Red rivers, respectively (see Perttula 2015:Table 1). Red-slipped sherds are well represented in the fine wares from pre-A.D. 1400 Caddo sites at Lake Fork Reservoir in the upper Sabine River basin (Bruseth and Perttula 1981:Table 5-4).

\section{Ceramic Pipe Sherd}

The one ceramic pipe sherd is a rim to a long-stemmed Red River style long-stemmed pipe (see Hoffman 1967). The rim sherd is tempered with burned bone, has $5.4 \mathrm{~mm}$ thick pipe bowl walls, and the bowl height is ca. $20.0 \mathrm{~mm}$. This rim sherd is probably from a var. Graves Chapel Red River pipe (see Hoffman 1967:9).

\section{Daub}

There are three pieces of daub in the surface collections from the Colony Church site. Their occurrence at the site suggests that there is at least one burned grass and thatch Caddo structure preserved in the 


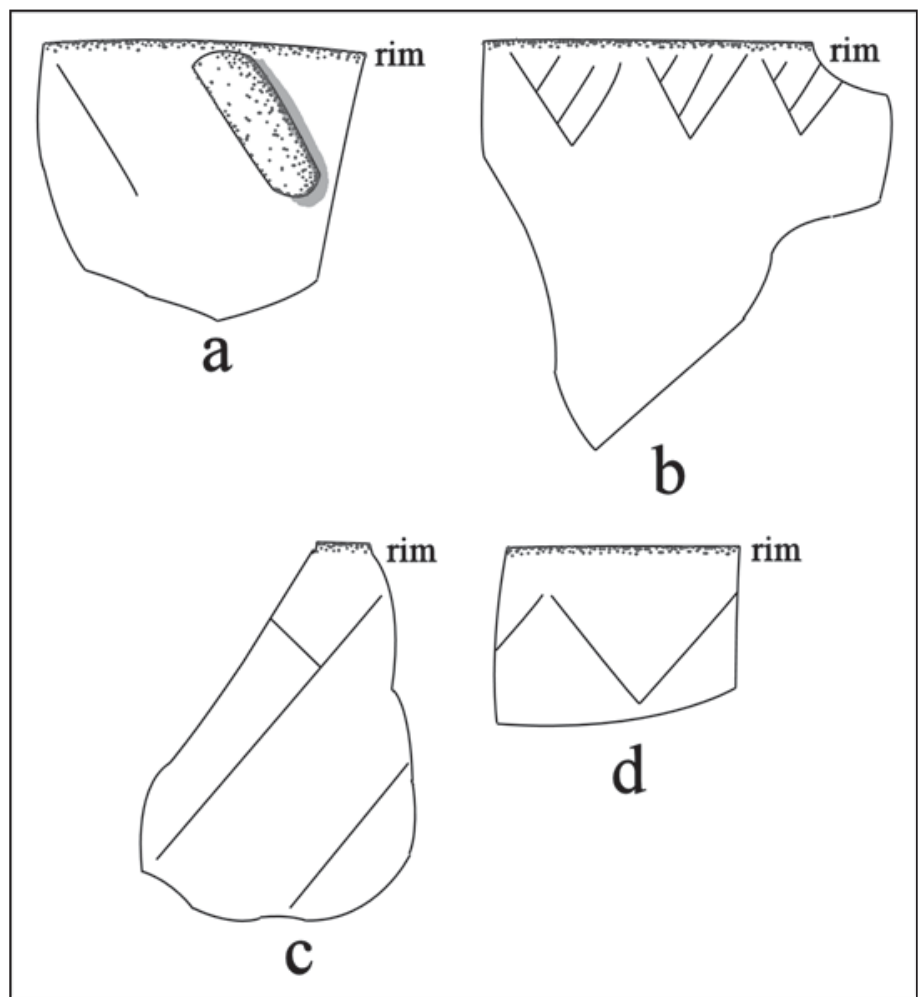

Figure 4. Decorative elements on fine ware rim sherds: a, engraved-appliqued; b, engraved; c-d, engraved-red-slipped.

archaeological record there-either under the mound or in habitation areas on the alluvial terrace - that had been covered with wattle and daub when it was built by Caddo peoples.

\section{SUMMARY AND CONCLUSIONS}

The Colony Church site (41RA31) is an ancestral Caddo mound center on a tributary to the Sabine River in the upper Sabine River basin. It was recorded in the late 1960s prior to the anticipated construction of Mineola Reservoir, but the reservoir was never constructed. The site, estimated to cover ca. 1.5 acres of an alluvial terrace along Big Creek, had habitation areas as well as two low (ca. $1 \mathrm{~m}$ in height) earthen mounds between 10-20 m in diameter. Although the mounds have not been excavated, it is likely that they were built by a Caddo community to cover the remains of important grass and thatch-covered structures that were used to hold religious and political rituals and ceremonies; when the structures were no longer in use and were to be abandoned, they were burned down and covered with sediments, creating a low constructed earthen mound.

The recovered artifacts from the Colony Church site indicate that the first use of the site took place during the Woodland period (ca. 500 B.C. to A.D. 800), but the principal settlement was by Caddo peoples. The occurrence of sherds from Canton Incised, Sanders Engraved, and Sanders Plain vessels in the ceramic assemblage strongly suggests that the Colony Church site was occupied - and the mounds constructed-during the Middle Caddo period (ca. A.D. 1200-1400). It is one of a number of known Middle Caddo period mound centers in the upper Sabine River basin (Perttula 1989, 1994). 


\section{ACKNOWLEDGMENTS}

I thank Jonathan Jarvis at the Texas Archeological Research Laboratory at The University of Texas at Austin for facilitating my access to the collections and records from the Colony Church site. Lance Trask prepared the figures in the article.

\section{REFERENCES CITED}

Brown, J. A.

1996 The Spiro Ceremonial Center. The Archaeology of Arkansas Valley Caddoan Culture in Eastern Oklahoma. 2 Vols. Memoir No. 29. Museum of Anthropology, University of Michigan, Ann Arbor.

Bruseth, J. E. and T. K. Perttula

1981 Prehistoric Settlement Patterns at Lake Fork Reservoir. Texas Antiquities Permit Series, Report No. 2. Texas Antiquities Committee and Southern Methodist University, Austin and Dallas.

Girard, J. S., T. K. Perttula, and M. B. Trubitt

2014 Caddo Connections: Cultural Interactions within and beyond the Caddo World. Rowman \& Littlefield, Lanham, Maryland.

Hoffman, M. P.

1967 Ceramic Pipe Style Chronology Along the Red River Drainage in Southwestern Arkansas. The Arkansas Archeologist 8(1):4-14.

Malone, J. M.

1972 Archaeological Reconnaissance at Proposed Mineola Reservoir. Archeological Survey Report No. 10. Texas Historical Survey Committee, Austin.

Perttula, T. K.

1989 A Study of Mound Sites in the Sabine River Basin, Northeast Texas and Northwest Louisiana. Institute of Applied Sciences, University of North Texas, Denton.

1994 Caddoan Mound Sites in the Sabine River Basin of Northeast Texas. Caddoan Archeology Newsletter 4(4):4-19.

2015 East Texas Caddo Ceramic Sherd Database. Journal of Northeast Texas Archaeology 51, in press.

Suhm, D. A. and E. B. Jelks (editors)

1962 Handbook of Texas Archeology: Type Descriptions. Special Publication No. 1, Texas Archeological Society, and Bulletin No. 4, Texas Memorial Museum, Austin. Reprinted in 2009, Gustav's Library, Davenport, Iowa. 